\title{
Local Knowledge on the Use of Swertia chirayita as Traditional Medicine: Conservation challenges in Sikkim Himalaya, India
}

\author{
Bharat K. Pradhan and Hemant K. Badola
}

\section{Research}

\begin{abstract}
Swertia chirayita (Roxb.) Buch.-Ham. ex C.B.Clarke (Gentianaceae) has been used as a traditional medicine, but this knowledge is eroding with modernization.This study attempted to understand the perception and knowledge of people about the species use and conservation in four districts of Sikkim Himalaya. A questionnaire survey was used for data collection. S. chirayita is highly used for treating fever and cold and cough by both male $(p<0.001$; $F=63.72)$ and female $(p<0.001 ; F=86.16)$ respondents. Over $92 \%$ of respondents administer the species, as medicine, orally in the form of decoction. The perception on the market potential of $S$. chirayita was significantly high amongst both male $(p<0.001 ; F=39.27)$ and female $(p$ $<0.001$; $F=30.46$ ) respondents. In Sikkim, a majority of respondents $(p<0.05)$ consider habitat destruction and human disturbances as the chief causes of natural population decline of $S$. chirayita.
\end{abstract}

\section{Introduction}

Swertia chirayita (Roxb.) Buch.-Ham. ex C.B.Clarke, (Gentianaceae) is a medicinal herb from the Himalaya region commonly called chirayita. It is extracted unsustainably from its natural habitat and in huge quantity. In addition, habitat destruction from various natural calamities and human activities, such as development, has likely made the species threatened. It has been prioritized for immediate conservation through ex-situ cultivation (see Badola \& Pradhan 2011). In Sikkim, a policy has been formulated by the state government to support commercial cultivation, processing, and marketing of medicinal plants, including S. chirayita, with an aim to provide sustainable alternative sources of income to the rural populace. Further, a scientific and technical cultivation package has been developed for the species by the GB Pant Institute of Himalayan Environment and Development (Badola \& Pradhan 2011), which has been under trial elsewhere.

The species has long been used as medicine, both in the codified as well as folk systems. The earliest recorded use is in the Charaka Samhita Sutra ( $3^{\text {rd }}$ to $2^{\text {nd }}$ century BCE), where the species is recommended for reducing fever (jvaraghna) and purifying breast milk (stanyasodhana). The medicinal efficacy of $S$. chirayita is officially registered and recognized in the Indian pharmaceutical codex, the British pharmacopoeia, and in different Indian traditional systems of medicines, such as Ayurveda, Unani, Siddha, and Tibetan (Sharma et al. 2008). The whole plant of $S$. chirayita is used in traditional medicine to treat fever, malaria, cough, cold, stomach ache, skin diseases, intestinal worms, and diarrhea (Badola \& Pradhan 2013, Pradhan $\&$ Badola 2008). The plant is also used in the preparation of branded herbal drugs: Diabegon, D-400, Chirayita tablet, GlucoBuster, DBCare, Himoliv, and Melicon V. It is one of the ingredients in Ayurvedic formulations such as Kabdeen (for treating viral hepatitis), Sudarshan churna,

\section{Correspondence}

Bharat K. Pradhan, Sikkim Biodiversity Conservation and Forest Management Project, Department of Forest, Environment and Wildlife Management, Government of Sikkim, Forest Secretariat, Deorali 737102, Gangtok, Sikkim, INDIA. bharatprdhn@gmail.com

Hemant K. Badola, Biodiversity Conservation Core Group, G.B. Pant Institute of Himalayan Environment and Development, Sikkim Unit (Pangthang), PO Box 40, Gangtok 737101, Sikkim, INDIA. hkbadola@gmail.com, hkbadola@rediffmail.com

Ethnobotany Research \& Applications 14:345-355 (2015)

Published: 07 December 2015 
Mahasudarsana churna, Kiratatiktadai kvatha, Bhunimbadi kvatha, Kiratadi taila (all for treating fever), Chandra Prabati (for cancer), Palas abijadi churna (anthelmintic), Dermafex oil (for skin problems), and as hair vitalizers.

Despite its various uses over the centuries, the knowledge on the traditional use of $S$. chirayita is thought to be declining all over the Himalaya region. This may be due to the loss of interest among younger generations and the easy accessibility to modern health care facilities (Pradhan \& Badola 2008). Its use is now restricted to a handful of individuals in remote areas, especially to elderly people who still prefer and believe the traditional health care system to be more effective than allopathic medicine.

Several studies have tried to document the ethnomedicinal use of the species targeting specific tribes or regions (Pradhan \& Badola 2008, Badola \& Pradhan 2013) and patterns of use. The present study was carried out with an aim of understanding the people's perceptions and knowledge on the use of $S$. chirayita in different areas of Sikkim. The study further aimed to understand people's knowledge about its trade potential, existing threats, and conservation perspectives in Sikkim.

\section{Study area}

The study was carried out in four districts of Sikkim, India (Figure 1). The state of Sikkim lies between $27^{\circ} 04^{\prime} 46^{\prime \prime}$ and $28^{\circ} 07^{\prime} 48^{\prime \prime}$ north latitudes and 88 $58^{\prime \prime}$ and 88 $55^{\prime} 25^{\prime \prime}$ east longitudes, at altitudes ranging from 220 masl to 8598 masl, covering an area of $7096 \mathrm{~km}^{2}$. Sikkim has temperatures varying from sub-tropical in the southern parts to cold deserts in the north. On the basis of variability in altitudes, Sikkim is divided into three different vegetation zones: tropical, temperate, and alpine with distinguishable phytodiversity.

For administrative purposes, Sikkim is divided into four districts: East, West, North, and South. Of these four districts, East District-especially the capital Gangtok being cosmopolitan-is the most populated while North District is the least populated but has the largest area. Sikkim is mainly inhabited by the three ethnic communities: Nepali, Bhutia, and Lepcha, of which the Nepali community represents over $50 \%$ of the population and is dominant in the East, West, and South districts. The North District is dominated by the Lepcha and Bhutia communities. Being an agrarian state, a majority of the populace practices agriculture, especially large cardamom and ginger farming and animal husbandry; nevertheless, at present, tourism

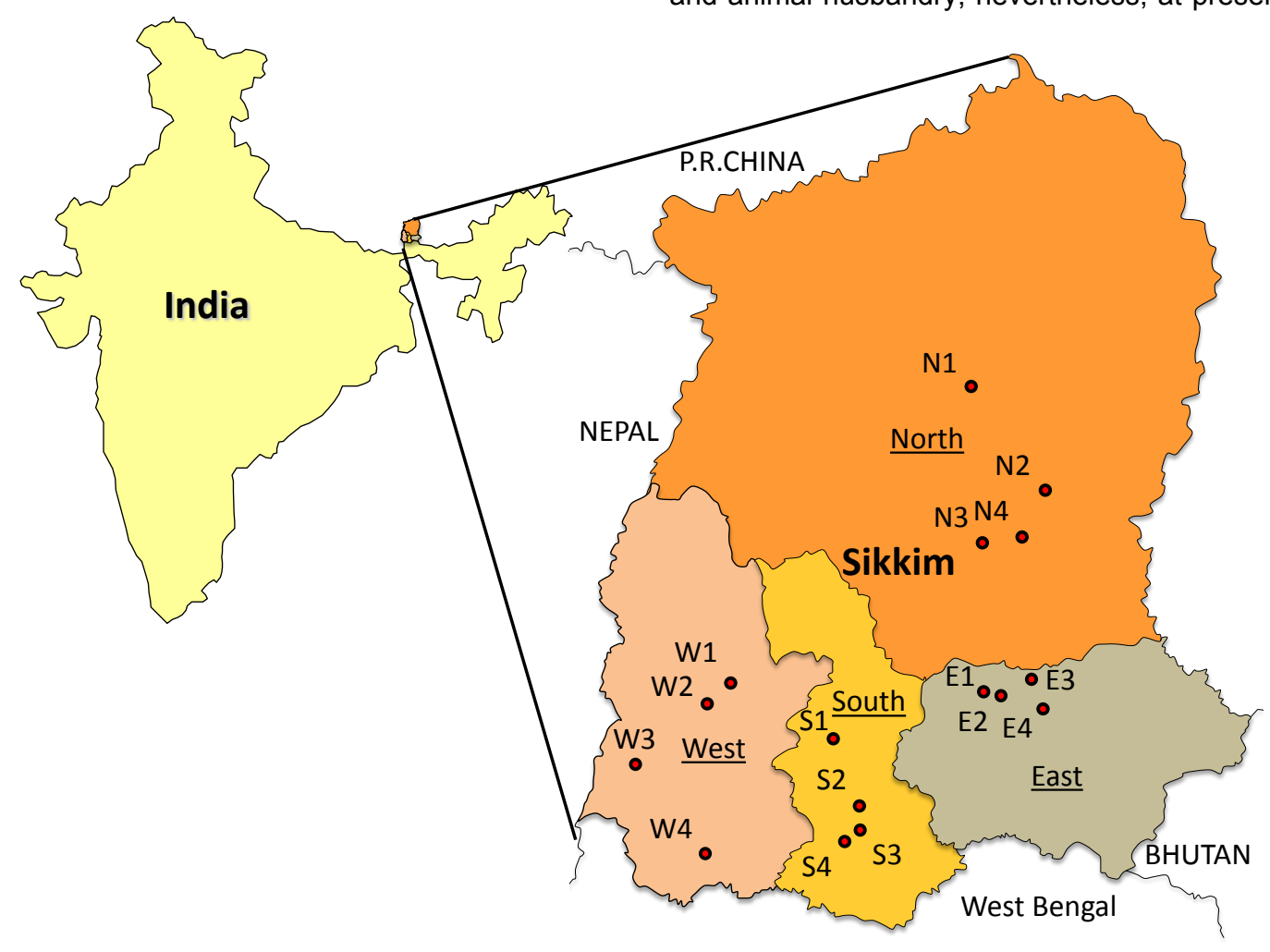

Figure 1. Study villages in four districts (West, East, North, and South) of Sikkim, India. Villages: West District (W1) Yuksom, (W2) Khecheopalri, (W3) Sopakha, and (W4) Gumpa Dara; East District (E1) Pangthang, (E2) Upper Luing, (E3) Phengla, and (E4) $2^{\text {nd }}$ mile (Tsomgo Road); North District (N1) Lachen, (N2) Chungthang, (N3) Saffo, and (N4) Ship gyer; South District (S1) Ravangla, (S2) Damthang, (S3) Jaubari, and (S4) Chamgaon. 


\section{Pradhan \& Badola - Local Knowledge on the Use of Swertia chirayita as Traditional Medicine: Conservation challenges in Sikkim Himalaya, India}

has emerged as one of the main sources of income generation.

\section{Methods}

Ethnomedicinal use of S. chirayita was studied from 2005 to 2010 targeting a total of 16 randomly selected villages covering all the four districts of Sikkim, i.e., 4 villages in each district (Figure 1). In each village, 20 respondents (male and female, 10 each) of age above 30 years were selected, irrespective of culture and category. The survey was not restricted to door to door, but people working in the field, agricultural lands, on the roadsides, etc. were also included, provided they had lived in the area for over 20 years. The interviews were conducted one on one, using a structured format mainly addressing 11 questions (Appendix 1).

Analysis of the results is based upon an assumption that there is a large market potential for this species and "awareness" of this potential is a positive attribute. Analyses of responses about $S$. chirayita use (including use frequency, market potential, population availability, and potential causes of population decline) were done using Microsoft Excel. One-way ANOVA was carried out and in- terpretations were made to analyze the differences (LSD, $\alpha=0.05$ ) in knowledge and perceptions about $S$. chirayita based by gender and districts in Sikkim.

\section{Results}

In total 320 individuals were interviewed. Interviewees ranged in age between 30 to 87 years and belonged to 5 different ethnic communities (Nepali 30\%, Limboo 15\%, Sherpa 10\%, Bhutia 24\%, and Lepcha $21 \%$ ).

A summary of use responses for $S$. chirayita is reported in Figure 2. In the study area $S$. chirayita is used to treat multiple diseases. Treatment of fever, cold, and cough is common by both males ( $p<0.001 ; F=63.72$ ) and females $(p<0.001 ; F=86.16)$. Other treatments such as stomach ache, diarrhea, and dysentery are less common. Knowledge of the use of $S$. chirayita for treating ailments was comparable between male and female respondents despite interdistrict variation.

Use frequency is reported in Figure 3. Differences between genders across districts suggested that the use frequency of species was greater in East and South districts among male and female respondents respectively.

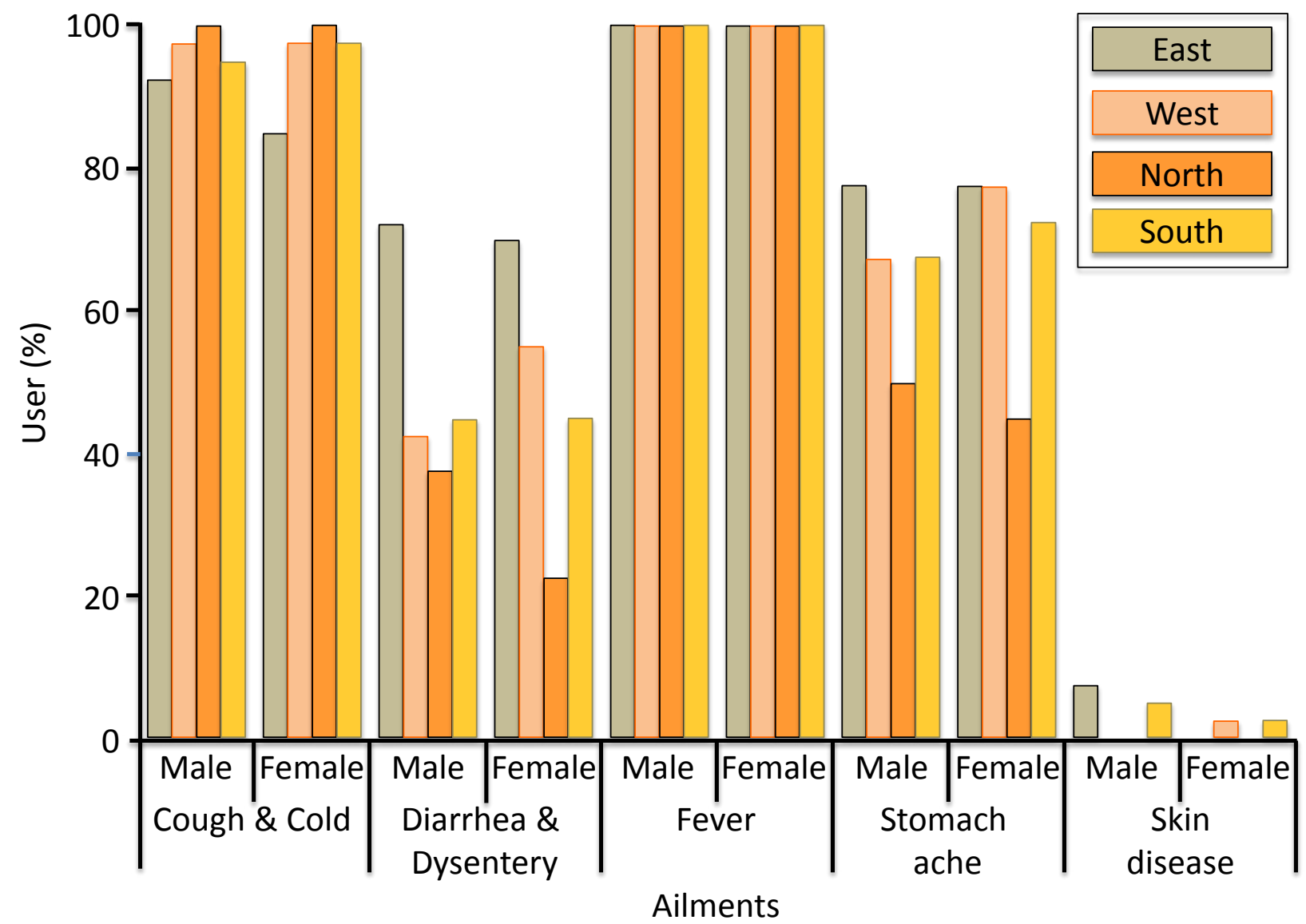

Figure 2. Response $(n=320)$ on the use of Swertia chirayita (Roxb.) Buch.-Ham. ex C.B.Clarke in Sikkim, India. 


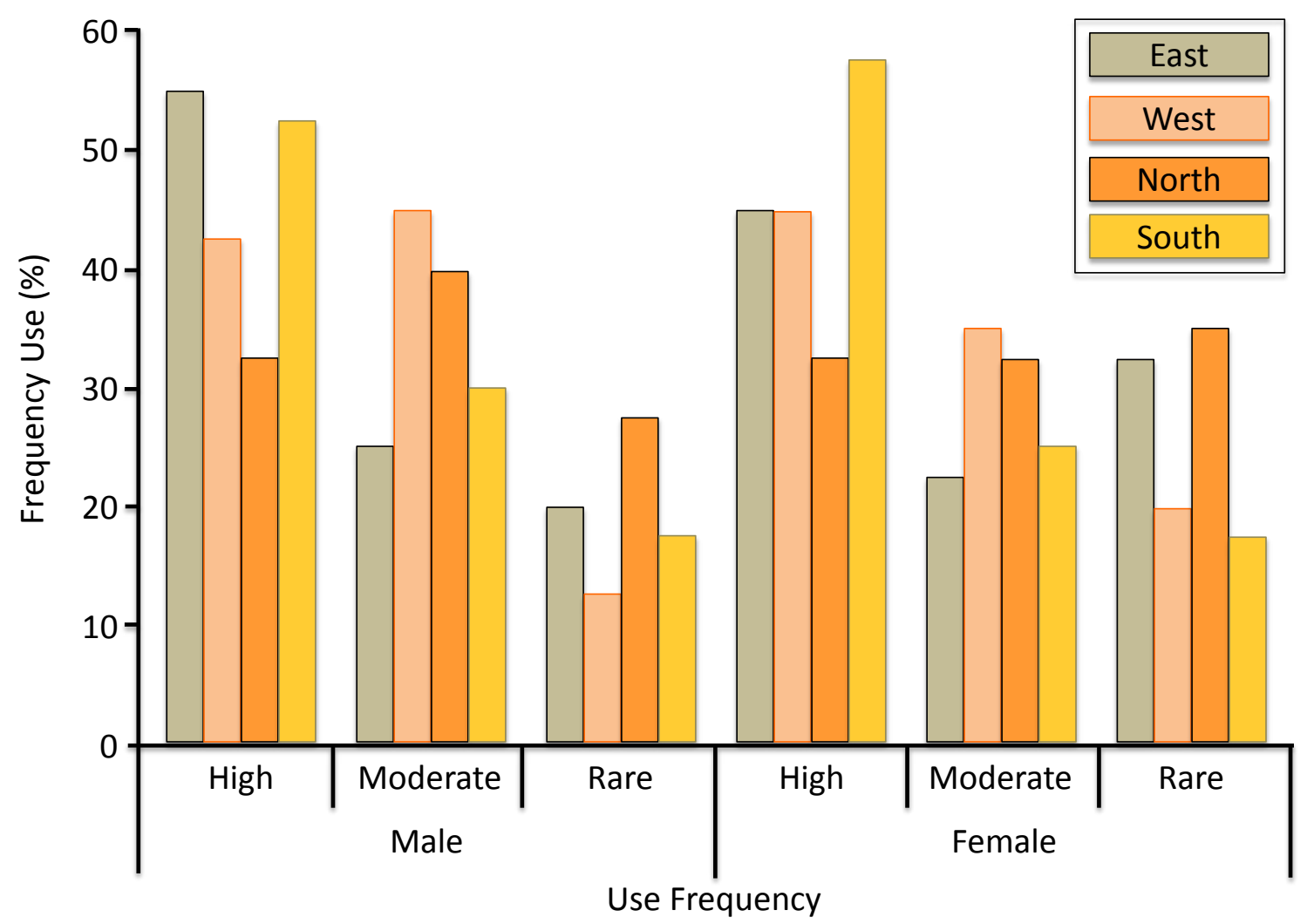

Figure 3. Use frequency of Swertia chirayita (Roxb.) Buch.-Ham. ex C.B.Clarke by respondents $(n=320)$ in Sikkim, India.

The highest number of male respondents reported high use frequency in the West and North districts; whereas, the majority of female respondents indicated high use frequency in West District but not in North District.

Cumulatively for the four districts, over $92 \%$ of respondents administer the medicine orally in the form of a decoction, rather than through direct consumption (males: $4 \%$, females: $5 \%$ ). Some respondents also reported the external application of the species in the form of paste for curing skin problems (male: $3 \%$; female 1\%, cumulative value for four districts), but in North District, no one reported its external application. Cumulatively, $88 \%$ of the male and $95 \%$ of the female respondents in surveyed villages shared that they collect and store plants or plant parts for later use, while the remaining respondents use fresh plant or plant parts. Respondents (males $73 \%$, females $71 \%$ ) suggested that the plant is more effective in its reproductive stage compared to rosette stage (males and females $1 \%$ each) or young vegetative stage (males and females $2 \%$ each). However, according to $24 \%$ males and $26 \%$ females, the plant is equally effective in all stages. Nonetheless, $100 \%$ respondents in all the study villages in Sikkim reported that the whole plant is used in treating various ailments.
Perceptions on marketing and cultivation are presented in Figure 4. Perceptions of a high market potential was significantly greater among both male ( $p<0.001$; $F=39.27$ ) and female $(p<0.001 ; F=30.46)$ respondents in Sikkim (Figure 4A). Comparatively, the people in East, West, and South districts perceive a higher market potential than those from North District. Cultivation prospects are more highly regarded by respondents in West (males and females $93 \%$ each) and South districts (males $88 \%$, females $77 \%$ ). These communities expressed high interest in being supplied with good quality seeds, scientific guidance, and marketing assistance. Conversely, only 53\% and $43 \%$ of the total male and female respondents in East District showed interest in S. chirayita cultivation. However, in North District, $90 \%$ of male and $100 \%$ of female respondents were not at all interested.

A majority of respondents consider the current availability of $S$. chirayita to be low (Figure 4B) in their surroundings and nearby forests. This is accompanied by a perception that there has been tremendous decline in its natural habitats (Figure 4C). Respondents had different perceptions explaining the cause of decline of natural populations of S. chirayita in Sikkim (Table 1). Cumulatively for the entire state, the highest percentage of respondents consider habitat destruction and human disturbances as the chief 

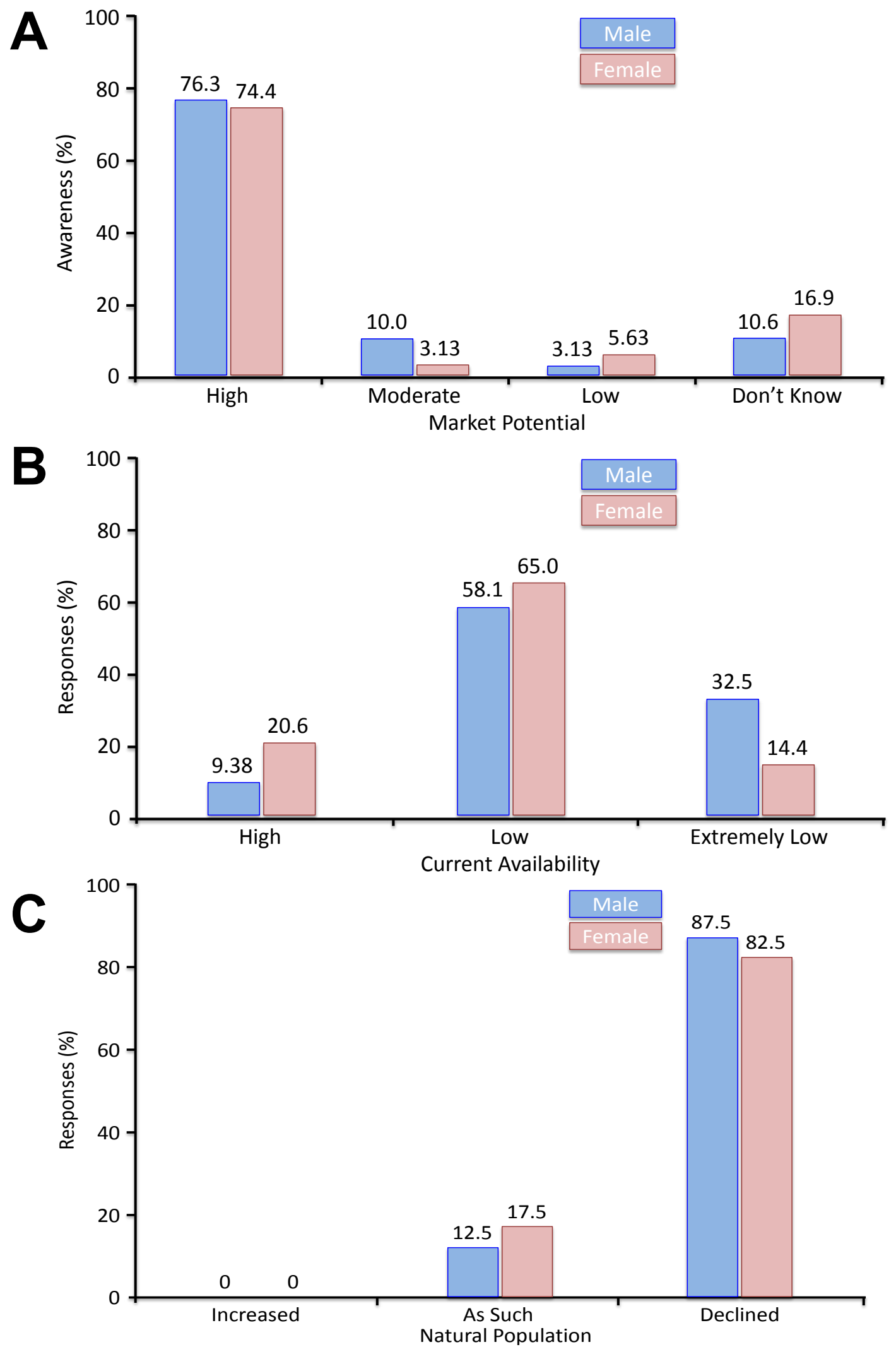

Figure 4. Respondent $(n=320)$ awareness about Swertia chirayita (Roxb.) Buch.-Ham. ex C.B.Clarke: A) market potential, B) current availability, and C) natural population (perceived present status) of S. chirayita in Sikkim, India. 
Table 1. Respondent perceptions $(n=320)$ on the possible cause of decline of the natural population of Swertia chirayita (Roxb.) Buch.-Ham. ex C.B.Clarke in Sikkim, India.

\begin{tabular}{|l|c|c|c|c|c|c|c|c|c|c|}
\hline \multirow{2}{*}{$\begin{array}{l}\text { Possible cause of } \\
\text { population decline }\end{array}$} & \multicolumn{9}{|c|}{ Male } & \multicolumn{4}{|c|}{ Female } & \multicolumn{3}{c|}{ Cumulative (\%) } \\
\cline { 2 - 13 } & \multicolumn{4}{|c|}{ Male } & Female \\
\cline { 2 - 13 } & East & West & North & South & East & West & North & South & & \\
\hline Over collection in the past & 22.5 & 77.5 & --- & 12.5 & 25.0 & 77.5 & --- & 20.0 & 28.1 & 30.6 \\
\hline $\begin{array}{l}\text { Faster regeneration of } \\
\text { other plants }\end{array}$ & 50.0 & 30.0 & --- & 35.0 & 45.0 & 15.0 & --- & 27.5 & 28.8 & 21.9 \\
\hline Habitat destruction & 60.0 & 42.5 & 52.5 & 60.0 & 47.5 & 67.5 & 40.0 & 45.0 & 53.8 & 50.0 \\
\hline Natural calamities & 40.0 & 10.0 & 22.5 & --- & 27.5 & 15.0 & 27.5 & --- & 18.1 & 17.5 \\
\hline Human disturbances & 50.0 & 52.5 & 20.0 & 37.5 & 77.5 & 50.0 & 30.0 & 37.5 & 40.0 & 48.8 \\
\hline
\end{tabular}

causes of natural population decline $(p<0.05)$. In East District, a larger number of male respondents $(60 \%)$ feel that habitat destruction is the primary cause of population decline for S. chirayita while $78 \%$ of the female respondents think human disturbances is the primary cause. In West District, the respondents were of the opinion that over-exploitation in the past has caused tremendous degradation in S. chirayita populations in their areas. Simultaneously, male $(53 \%)$ respondents claim human disturbance and female $(68 \%)$ respondents claim habitat destruction as a leading cause of population decline. Similarly, in North and South districts respondents reckoned habitat destruction to be the prime cause of population decline.

Human disturbances were categorized into five types (Table 2). As per the respondents' understanding, unsustainable collection of juvenile plants and seeds of S. chirayita for nursery propagation/plantation has been a serious problem in West and South districts, leading to depletion of its natural populations. An exception is in North District where such activities were not reported. In addition, fuel wood/fodder/NTFP (non-timber forest product) collection and grazing are among other human disturbances identified as problems. Grazing, except in East District, however, is not considered to be a big threat, as it has been banned since 1998, especially in protected areas including reserve forests in Sikkim.

\section{Discussion}

Despite dominance of allopathic medicine, folk traditional medicine still exists in remote areas of Sikkim where people normally do not visit health centers for the minor problems (Pradhan \& Badola 2008). For example, among the Lepcha and Limboo tribes, traditional medicine is applied but also used with allopathic medicine when needed (Badola \& Pradhan 2013, Pradhan \& Badola 2008). In these areas, traditional knowledge is transmitted from fathers to sons and rarely to daughters; therefore, as a whole, males hold relatively more traditional knowledge. However, while using routine medicine to treat local ailments, women possess more knowledge than the men because they are the ones who actually are involved in exchanging information and knowledge through verbal communications.

In Sikkim, it is common to see the coexistence of numerous cultural communities in an area, which likely has several advantages such as cross-cultural exchange of information on the use of plants as medicine. This builds on strengths of differential cultural experiences from being exposed to different plant species and ailments (SaslisLagoudakis et al. 2011). Even when different cultural experiences are with the same species, the use pattern and the types of disease treated may differ (Badola \& Pradhan 2013, Pradhan \& Badola 2008). In the present study, some of the respondents reported direct consumption of chirayita by chewing, and some, especially Sherpa com-

Table 2. Respondent perceptions $(n=320)$ about major human disturbances causing threat to Swertia chirayita (Roxb.) Buch.-Ham. ex C.B.Clarke in Sikkim, India. NTFP = non-timber forest product.

\begin{tabular}{|c|c|c|c|c|c|c|c|c|c|c|}
\hline \multirow[b]{3}{*}{ Human disturbances } & \multicolumn{8}{|c|}{ Respondent (\%) } & \multicolumn{2}{|c|}{ Cumulative (\%) } \\
\hline & \multicolumn{4}{|c|}{ Male } & \multicolumn{4}{|c|}{ Female } & \multirow[t]{2}{*}{ Male } & \multirow[t]{2}{*}{ Female } \\
\hline & East & West & North & South & East & West & North & South & & \\
\hline Fuel wood collection & 25.0 & 14.3 & 75.0 & 26.7 & 19.4 & 20.0 & 41.7 & 13.3 & 28.1 & 21.8 \\
\hline Fodder collection & 15.0 & 19.1 & 12.5 & 0.0 & 19.4 & 15.0 & 33.3 & 6.7 & 12.5 & 18.0 \\
\hline NTFP collection & 30.0 & 19.1 & 12.5 & 13.3 & 29.0 & 10.0 & 8.33 & 40.0 & 20.3 & 23.1 \\
\hline Uprooting/seed collection & 20.0 & 47.6 & 0.0 & 53.3 & 9.7 & 45.0 & 0.00 & 26.7 & 34.4 & 20.5 \\
\hline Grazing & 10.0 & --- & --- & 6.7 & 22.6 & 10.0 & 16.7 & 13.3 & 4.69 & 16.7 \\
\hline
\end{tabular}




\section{Pradhan \& Badola - Local Knowledge on the Use of Swertia chirayita as Traditional Medicine: Conservation challenges in Sikkim Himalaya, India}

munities, revealed its external application in the form of a paste to treat skin diseases.

Persistence of traditional uses of $S$. chirayita is likely due to its multiple uses and reasonable availability in the area. Nevertheless, this use may not continue for long or may be restricted to certain groups since less than half of males and females in this study use the plant. This may be attributed to (1) disappearance of the species from nearby places and/or (2) easy accessibility to allopathic health care.

Unsustainable collection of medicinal plants for traditional use is probably unintentional (based on our experience and personal interaction with villagers) in most of the cases. Plants are collected as and when encountered, without considering their age, form, and stage, for later use in dried forms. This is commonly true elsewhere for all sections of people irrespective of their culture and country (Tetik et al. 2013). Presumably this is mainly done because the plants may not be available all the time or it may take a long walk to collect the species, which is not feasible during urgency. Most respondents in the present study reported the collection of fresh plants because they do not want to put effort in collecting and drying the material for later use. Further, people believe that fresh plants or plant parts are more effective than dried plants for treating diseases because of loss of efficacy upon drying (Lulekal et al. 2013). Loss of efficacy has been noted in other locations (Fennell et al. 2004). Because of fresh collection habits, the frequency of collection may be high which may threaten the species existence (Megersa et al. 2013).

The efficacy of medicinal plants depends on the presence of active constituents (Maroyi 2013). A related species from Tibet, Swertia mussotii Franch., has been found to vary in active constituency levels with bud growth stage being highest (Yang et al. 2005). This would indicate higher efficacy of mature plants over the immature ones, and supports the belief of respondents about greater efficacy of reproductive stages of $S$. chirayita.

Our survey revealed that people in Sikkim are aware of market potential for $S$. chirayita. The species used to be collected unsustainably from the forest areas in Sikkim and was exported to markets in Siliguri, West Bengal (India), and to adjacent Nepal and Bhutan, before imposition of a ban on medicinal plant collection for 5 years in 2001. The ban covered forest reserves held by the Sikkim government. This was done to allow for plant population regeneration. Nevertheless, after the imposition of the ban on wild harvesting, the people lost interest in chirayita collection, and as of now, there is no such data available on the collection and trade of $S$. chirayita from Sikkim. The species still has commercial cultivation potential. The initiative of the Government of Sikkim to support commercial cultivation of medicinal plants and the effort of the GB Pant Institute of Himalayan Environment and De- velopment in developing scientific and technical cultivation package of $S$. chirayita have been acknowledged by farmers in Sikkim. However, the farmers were not able to take up mass cultivation so far because of lack of scientific and technical guidance as well as existing marketing problems. Now they are ready to take up mass cultivation which according to them will provide sustainable incomes. It is interesting to note that people belonging to Nepali and Limboo communities, and a few Sherpa, were highly interested in taking up mass cultivation of $S$. chirayita, but a majority of Lepcha and Bhutia respondents were not at all interested because according to them, the crop can be harvested only after three years and there is no guarantee that it may fetch substantial profit. Further, among the districts, the respondents from West and South districts showed more interest because they have private lands where they can undertake the cultivation. Conversely, in East District, irrespective of their interest, a majority of the respondents had problems associated with land holding because they are residing in and around protected areas and reserve forests, where such activities cannot be carried out. Some of the progressive farmers from Utteray village in west Sikkim had already initiated mass scale cultivation of $S$. chirayita after buying seeds from Nepal, but they faced major problems in processing and marketing because the crop had to be taken to Siliguri market in West Bengal (India). At market, they encountered very low prices in comparison to their inputs, so they gave up chirayita cultivation.

Over the past couple of decades, increasing demand has led to depletion of natural resources throughout the Himalayan region (Sharma et al. 2006) including medicinal plants. The present survey in Sikkim points to the same fate for $S$. chirayita. The respondents indicated that, in the past, there has been unsustainable collections of $S$. chirayita from Sikkim by untrained and unskilled laborers, who did not care to consider the age of the plants during collection. Rai et al. (2000) examined collection of approximately 35 quintal of $S$. chirayita from different parts of Sikkim during 1990-1991 which caused a harvesting pressure of $0.48 \mathrm{~kg}$ per $\mathrm{km}^{2}$. This resulted in low regeneration and gradual disappearance of chirayita from their area. Uprooting of the juvenile plants and collection of seeds from the wild for nursery plantation and propagation is yet another major threat for $S$. chirayita. Such practices are not advisable from a conservation point of view because if juveniles are destroyed before maturing and completing their life cycle, the species may become vulnerable to extinction due to lack of regeneration.

Prior to 1998, the forests in Sikkim were open for grazing and other activities, but since then this has been restricted. The cattle were removed from forest areas, which lessened human intrusion into the forest. According to the respondents, the ban on grazing promoted the invasion of unpalatable species such as Edgeworthia gardneri (Wall.) Meisn., Ageratina adenophora (Spreng.) R.M.King 
\& H.Rob., Diplopterygium giganteum (Wall. ex Hook.) Nakai, and Osbeckia stellata Buch.-Ham. ex Ker Gawl. in open areas that are normally suitable niches for $S$. chirayita. This has likely restricted the species to small pockets with gradual disappearance from the forest areas. Landslides and forest fires are common natural calamities in Sikkim, of which $S$. chirayita is mostly affected by monsoon landslides according to respondents. Ironically, landslides may also have positive impacts, creating open conditions where $S$. chirayita seedlings may emerge.

\section{Conclusion and Recommendations}

The erosion of long-practiced traditional knowledge of medicinal plants is a global phenomenon, which is happening faster because of competition from allopathic medicine and disinterest of younger generations. The existence of such practices is increasingly limited to remote areas where people are away from health centers. Habitat destruction, human disturbances, and over-exploitation have emerged as likely factors responsible for the decline in the natural populations of S. chirayita in Sikkim.

On the basis of the perceptions of people in Sikkim, the following recommendations are made:

1. It is imperative to conserve both the traditional system of medicine and the natural resources from depletion. For this, government as well as non-government agencies have to play roles, such as giving recognition to the herbal practitioners, providing them a monthly honorarium, motivating them to undertake mass scale plant cultivation, and developing direct linkages between pharmaceutical companies and farmers.

2. In the case of S. chirayita, minor human interference is likely advantageous in the forested areas. In such cases, the government can frame policies about minor clearing of areas of chirayita habitat in order to avoid invasion of weed species, sustainable rotational harvesting in forest territorial ranges with minimal royalties charged, and demarcating area for these activities.

3. Strict guidelines should be framed to avoid collection of juveniles and young plants, allowing collection of only mature plants after dispersing the seeds.

4. Re-introduction of ex-situ cultivated plants of $S$. chirayita to their natural habitat (using genetic material of the same sources) will certainly help local entrepreneurs to earn sustainable incomes that permit in-situ conservation of plants like $S$. chirayita and preserve folk traditional medicine.

\section{Acknowledgments}

This research was carried out under the In-House programme of the Institute. We are grateful to Dr. P.P. Dhyani, Director, and Dr. L.M.S. Palni and Dr. U. Dhar (Ex-Directors) of the Institute for providing necessary facilities and encouragement. This research would not have been possible without the support of the local people of the study villages. We would like to give special thanks to them for sharing their long-conserved valuable knowledge with us. We thank the State Forest Department, Government of Sikkim, for support during field studies and Miss Hemlata Rai of SBFP for preparing the location map of the study area.

\section{Literature Cited}

Badola, H.K. \& B.K. Pradhan. 2011. Economic viability of cultivation of Swertia chirayita, a high value endangered medicinal herb in Himalaya. Zeitschrift für Arznei \& Gewürzpflanzen 16(3):118-124.

Badola, H.K. \& B.K. Pradhan. 2013. Plants used in healthcare practices by Limboo tribe in south-west of Khangchendzonga Biosphere Reserve, Sikkim, India. Indian Journal of Traditional Knowledge 12(3):355-369.

Fennell, C.W., M.E. Light, S.G. Sparg, G.I. Stafford \& J.V. Staden. 2004. Assessing African medicinal plants for efficacy and safety: Agricultural and storage practices. Journal of Ethnopharmacology 95:113-121. doi:10.1016/j/ jep.2004.05.025.

Lulekal, E., Z. Asfaw, E. Kelbessa \& P. Van Damme. 2013. Ethnomedicinal study of plants used for human ailments in Ankor district, North Shewa zone, Amhara Region, Ethiopia. Journal of Ethnobiology and Ethnomedicine 9:63. doi:10.1186/1746-4269-9-63.

Maroyi, A. 2013. Traditional use of medicinal plants in south-central Zimbabwe: Review and perspectives. Journal of Ethnobiology and Ethnomedicine 9:31. doi:10.1186/1746-4269-9-31.

Megersa, M., Z. Asfaw, E. Kelbessa, A. Beyene \& B. Woldeab. 2013. An ethnobotanical study of medicinal plants in Wuyu Tuka District, East Welega zone of Oromia Regional State, West Ethiopia. Journal of Ethnobiology and Ethnomedicine 9:68. doi:10.1186/1746-4269-9-68.

Pradhan, B.K. \& H.K. Badola. 2008. Ethnomedicinal plant use by Lepcha tribe of Dzongu valley, bordering Khangchendzonga Biosphere Reserve, in North Sikkim, India. Journal of Ethnobiology and Ethnomedicine 4:22. doi:10.1186/1746-4269-4-22. 


\section{Pradhan \& Badola - Local Knowledge on the Use of Swertia chirayita as Traditional Medicine: Conservation challenges in Sikkim Himalaya, India}

Rai, L.K., P. Prasad \& E. Sharma. 2000. Conservation threats to some important medicinal plants of Sikkim Himalaya. Biological Conservation 93:27-33.

Saslis-Lagoudakis, C.H., E.M. Williamson, V. Savolaineen \& J.A. Hawkins. 2011. Cross-cultural comparison of three medicinal floras and implications for bioprospecting strategies. Journal of Ethnopharmacology 135(2):476-487. doi:10.1016/j.jep.2011.03.044.

Sharma, E., N. Chettri \& P. Gyamptsho. 2006. Advances in community based natural resource management in the Hindu Kush-Himalaya region. Pp. 24-28 in Proceedings of the Regional Workshop on the Capitalisation and Sharing of Experiences on the Interaction between Forest Policies and Land Use Pattern in Asia. Volume 1. Edited by P. Gyamptsho, B.K. Singh \& G. Rasul. International Centre for Integrated Mountain Development, Kathmandu, Nepal.
Sharma, N., S.G. Aggarwal, R.P. Kala \& A. Kurar. 2008. Analgesic activity of Swertia chirayita. World Journal of Pharmacology and Pharmaceutical Sciences 2(5):36673675.

Tetik, F., S. Civelek \& U. Cakilcioglu. 2013. Traditional uses of some medicinal plants in Malatya (Turkey). Journal of Ethnopharmacology 146(1):331-346, doi:10.1016/j. jep.2012.12.054.

Yang, H., C. Ding, Y. Duan \& J. Liu. 2005. Variation of active constituents of an important Tibet folk medicine Swertia mussotii Franch. (Gentianaceae) between artificially cultivated and naturally distributed. Journal of Ethnopharmacology 98:31-35. doi:10.1016/j.jep.2004.12.015. 
Appendix 1. Survey questions asked about chirayita (Swertia chirayita (Roxb.) Buch.-Ham. ex C.B.Clarke) in Sikkim, India. NTFP = non-timber forest product.

\begin{tabular}{|c|c|c|}
\hline \# & Question & Options \\
\hline 1 & \multicolumn{2}{|c|}{ For which ailments do you use chirayita? } \\
\hline & & open ended response \\
\hline 2 & \multicolumn{2}{|c|}{ What is your frequency of use? } \\
\hline & & high \\
\hline & & moderate \\
\hline & & rare \\
\hline 3 & \multicolumn{2}{|c|}{ How do you use it? } \\
\hline & & decoction (boiled and drunk) \\
\hline & & direct consumption \\
\hline & & external application \\
\hline 4 & \multicolumn{2}{|c|}{ Do you store plant material in advance or collect it fresh during the time of ailments? } \\
\hline & & collect and store \\
\hline & & use in fresh form \\
\hline 5 & \multicolumn{2}{|c|}{ In your experience, which morphological stage of chirayita is most effective? } \\
\hline & & rosette \\
\hline & & vegetative stem stage \\
\hline & & reproductive stage \\
\hline & & all stages \\
\hline 6 & \multicolumn{2}{|c|}{ Which part do you mostly use? } \\
\hline & & above ground \\
\hline & & below ground \\
\hline & & whole plant \\
\hline 7 & \multicolumn{2}{|c|}{ How high is the market potential of chirayita? } \\
\hline & & high \\
\hline & & moderate \\
\hline & & low \\
\hline & & don't know \\
\hline 8 & \multicolumn{2}{|r|}{$\begin{array}{l}\text { If you are provided with quality seeds, scientific guidance, or assured markets, would you go for large scale cul- } \\
\text { tivation of chirayita? }\end{array}$} \\
\hline & & yes \\
\hline & & no \\
\hline 9 & \multicolumn{2}{|c|}{ How do you perceive the availability of the chirayita population in your surrounding/nearby forests? } \\
\hline & & high \\
\hline & & low \\
\hline & & extremely low \\
\hline 10 & \multicolumn{2}{|c|}{ How do you perceive availability of chirayita over the past $10-15$ years in your surrounding areas? } \\
\hline & & increased \\
\hline & & as such \\
\hline & & declined \\
\hline
\end{tabular}


Traditional Medicine: Conservation challenges in Sikkim Himalaya, India

\begin{tabular}{|r|l|l|}
\hline$\#$ & Question & Options \\
\hline 11 & If declined availability, what do you think is the possible cause? \\
\hline \multirow{3}{*}{} & Over collection in the past \\
\cline { 2 - 3 } & faster regeneration of other plants \\
\cline { 2 - 3 } & habitat destruction due to road-widening and related activities \\
\cline { 3 - 4 } & natural calamities \\
\cline { 3 - 4 } & human disturbances (fuel wood/fodder/NTFP collection, uprooting/seed collection, grazing) \\
\hline
\end{tabular}


